\title{
Implementation of Customer Relationship Management (CRM) to Increase Customer Loyalty and Product Sales Volume at Alexander Stamps
}

\author{
Renee Yosua Hetharie \\ Master of Information Systems, Faculty of \\ Information Technology, Universitas Kristen Satya \\ Wacana \\ Salatiga, Indonesia
}

\author{
Eko Sediyono \\ Master of Information Systems, Faculty of \\ Information Technology, Universitas Kristen Satya \\ Wacana \\ Salatiga, Indonesia
}

\begin{abstract}
Customer is a substantial asset in industrial activity or organization. The continuance of a business exactly depends on the carefulness of observation of the industry to know what the customer's necessity, by then it can increase customer loyalty to the product. In fact, many industries unintentionally forget to do appropiate strategy of business to get customer's attention to their products. After interviewing Alexander Stamps Gallery, the researcher found that in this digital era, Alexander Stamps Gallery do not use any social media to sell, promote and give an update its products to their valuable customers. The aim of this research is to help Alexander Stamps Gallery to develop its business by using the power of social media to increase the customer loyalty and product sales volume at Alexander Stamps Gallery. The result of the research is that the implementation of Customer Relationship Management concept and the use of social media such as Instagram and Facebook as a marketing medium able to increase customer loyalty and product sales volume at Alexander Stamps Gallery.
\end{abstract}

\section{General Terms}

Customer Relationship Management (CRM), Information System, Social Media.

\section{Keywords}

Customer Relationship Management (CRM), Customer Loyalty Concept, Social Media.

\section{INTRODUCTION}

The development of the world of business and modern technology such as the present era makes business as a business opportunity that has great potential to generate large profits to business people who utilize information technology as a medium for promotion, marketing, retaining customers, etc. So that a challenge arises in maintaining a good relationship with customers and able to manage customer information quickly and accurately [1]. Today, the internet is an economic and social weapon that used to change the business world. The internet has changed the traditional business organization model and brought changes to its operations. This becomes a new paradigm in the business world where companies need to prepare the right strategies in order to maintain their business and of course retain customers in using the products produced [2].

Alexander Stamps Galery is a business which engaged in the sale of Philately objects. Objects offered by Alexander Stamps Gallery are various, among others are collections of stamps, money orders, first day cover, miniature shit to the old edition stamps that are difficult to obtain so the collection has a high selling price. For the progress of the company, in this technological era Alexander Stamps Gallery must utilize social media facilities as a means of promoting goods sold online which aims to maintain the existence of goods sales. Besides, Alexander Stamps Gallery must have the ability to set up a good business strategy so that the goods had been marketed increasingly recognized in the wider community. Analyzing the challenges being faced by the Alexander Stamps Gallery, the authors want to apply a concept of Customer Relationship Management (CRM) by using Instagram and Facebook social media as a media for promoting and selling goods, which aims to provide solutions to the Alexander Stamps Gallery in developing the business, so that the company can maintain customer loyalty and increase sales volume at Alexander Stamps Gallery.

The aim of this research is to help Alexander Stamps Galery in developing the company's business strategy using social media facilities, so that the presence of online sales can facilitate the company in managing and marketing online and also can retain customers so that they are always loyal to the company and increase sales volume at Alexander Stamps Gallery. In addition, the use of social media that is applied in this study can provide an overview to the ranks of business managers in order to be able to make changes following the development of existing technology so that they can follow what the customers need. The result of the implementation concept of Customer Relationship Management (CRM) in this study through the using of Instagram and Facebook give good effect toward Alexander Stamps Gallery, as the recent data said that sales volume of goods has increased significantly year by year since the implementation of the new strategy business through social media.

\section{THEORITICAL REVIEW}

Several previous studies relating to the implementation of Customer Relationship Management using social media tools such as done by Yanuar Insanaputra (2017), he has done research on CRM Adoption Patterns by Actors of Social Media Based on Online Shop. In his research, the author explained that the actors of Online Shop must know the exact steps that must be done by online shop actors, to achieve the criteria of success in doing business online, especially those based on social media. This research will also show how social media and CRM contribute to the CRM social actors. Therefore, it is very necessary to adopt CRM (social CRM) strategy for online shop players based on social media whose purpose is to help the online shop actors towards the criteria 
of a successful online shop. The results of this study show how the right steps and the best recommendations for online shop actors better and certainly towards the success criteria.

Another research that has been completed by Theresia Pradiani (2017) is about The Influence of Digital Marketing Marketing Systems Against Increased Sales Volume of Home Industry Products. That research conducted with the method of literature study by examining previous studies that discuss the use of technology, especially social media in terms of acceptance and also its use. In past, conventionally the seller made and sold their products only by order. But now, after having knowledge of social media the people get more orders rather than before knowing the use of social media. Digital marketing is seen as the best media as the most effective and efficient promotion tool and able to increase significant sales volume [4].

The last research is from Radius Tanone dan Richard G Mayopu (2018). They did the research about The Scial Media Analysis and Public Relation in Supporting E-CRM, A Case Study at PT. Gunung Slamat Slawi. On their study, the authors focused on the use of social media as a promotion or even to maintain the existence of products (tea) produced by PT. Gunung Slamat. The purpose of the research is to help PT. Gunung Slamat in developing its business startegy using social media such as Instagram, Twitter dan Facebook to retain customers. E-CRM concept expected to be achieved in accordance with the expectations of the company to increase sales [5].

\subsection{Customer Relationship Management}

Customer Relationship Management (CRM) is a strategy to manage connection and interaction between organization and potential customer. The system of CRM is to help company stay connected with customers, and increase profitability. Most of people usually refer to CRM system as a tool used for contact management, sales management, productivity, and so on. The main purpose of the CRM system is simply to improve business relationships [6].

Customer Relationship Management is considered important because CRM enabling business people to connect closely with customers, service users, colleagues, partners, and suppliers. Establishing good relationships and tracking prospects and customers is very important for customer acquisition and retention, which is the core of the Customer Relationship Management function. You can see it all in a simple and customizable dashboard which can tell you history between you and your customer, their order status, outstanding customer service issues, etc. Gartner predicts that by 2021, Customer Relationship Management technology will be the largest area of spending in corporate software. If you want to maintain your business, you know that you need a strategy for the future. For forward-thinking businesses, Customer Relationship Management is the framework for that strategy [7].

Benefits derived from the implementation of Customer Relationship Management is with collecting and managing data of customer interaction, making it accessible and actionable for all, and facilitating the data analysis, Customer Relationship Management offers many benefits and benefits. Benefits and advantages of Customer Relationship Management include: Improved contact management, good cross-team collaboration, increased productivity, empowered sales management, accurate sales forecasting, reliable reporting, increased sales metrics and increased customer satisfaction and retention [8].

\subsection{The Concept of Customer Loyalty}

Customer loyalty has an important role in a company, maintaining those mean improving financial performance and maintaining the survival of the company. This is the main reason for a company to attract and retain them. Two things that become the main considerations of the company in maintaining customer loyalty are: firstly because of the increasingly high cost of acquiring new customers in such a tight competition climate, secondly is the fact that the company's level of profitability is directly proportional to the growth of the relationship between the company and its customers permanently [9]

In general, companies focus on finding new customers as much as possible, while efforts to empower old customers are inattention. Even though the cost of finding new customer is greater than the cost of retaining old customer and making them loyal, customers who feel satisfied have not guaranteed customers will be loyal because, as reported by Harvard Business School Review, every year $15 \%-40 \%$ of customers who were initially satisfied then switch to competitors. In other words, satisfaction does not necessarily mean loyalty [10]. Loyalty is shown by actions taken by customers without any compulsion and pressure from any party. Furthermore Griffin (2003: 31) mentions the characteristics or attitudes carried out by loyal customers, those are:

1. Repeat purchases regularly,

Loyal customers with the product or service they buy will repeat the purchase more than twice at the same company regularly.

2. Buy outside of product and service line,

Furthermore, loyal customers will expand their loyalty to other products or services made by the same manufacturer. In the end they are loyal customers for the company forever.

3. Promote to others,

Loyal customers will show the attitude of rejection of other products or services for placing the trust and feel part of the company.

4. Not easily tempted by other products.

Loyal customers will not be interested in promotions or forms of offers given by other companies.

Based on the explanation above can be concluded that loyal customers will repeatedly use product and service from one company or even will increase their consumption of the another products a services from the same company. Loyal customers will not care about the products or services of competing companies, including the various promotions and attractions they offer. Customers assume that the risk of dissatisfaction with trying products or services from other companies will be greater than staying loyal to other companies' products or services. In addition, customers may recommend products to others that will benefit the company, in addition to adding customers, it is also an advertising tool that is effective and does not require additional costs.

\subsection{Social Media}

Social media is a way to communicate and interact by online. In the last ten years we have seen a surge in the number of social media users and the popularity of social media sites. 
Almost everyone with internet access uses social media in some form or another. This changes the way individuals and organizations communicate or interact with others. However, despite its popularity, most people have a very limited understanding of the scope and usefulness of Social Media as a whole. In Figure 1, the level of social media used in Indonesia in 2016 [11].

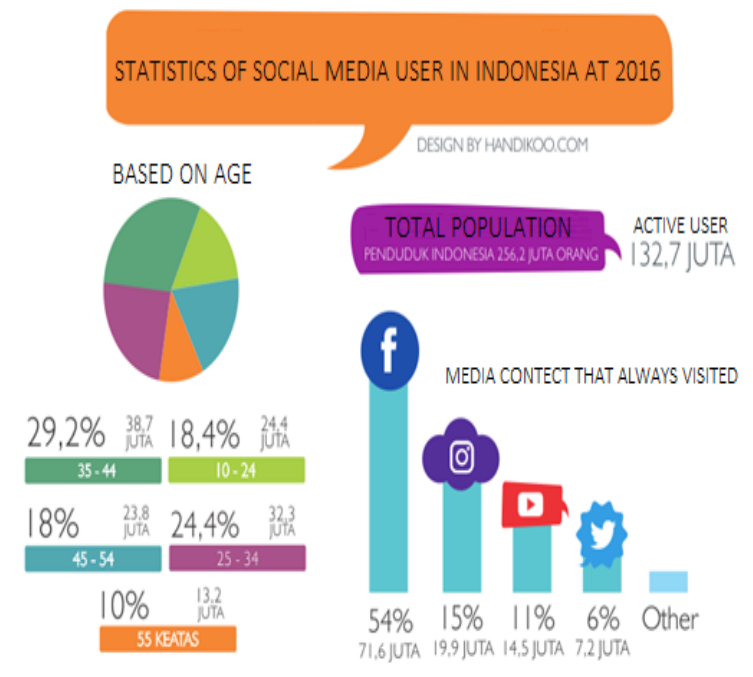

Figure 1. Statistics on the Use of Social Media in 2016

Marketing using social media is a powerful way for businesses of all sizes to reach prospects and customers. Your customers have interacted with brands through social media, and if you do not talk directly to your audience through social platforms that are often used like Facebook and Instagram, then you will miss that opportunity. Great marketing on social media can bring tremendous success to your business, creating loyal supporters and even encouraging the prospect of increasing sales volume [12].

\section{RESULT AND DISCUSSIONS}

The process of implementing Customer Relationship Management at Alexander Stamps Gallery aims to stabilize, treat and maintain a good relationship with the customers and colleagues who contributed directly or indirectly to the company. This is done as a company's strategy in developing a better business, so that it can achieve the expected goals which Customer Relationship Management acts as a regulator and controller of the course of a business process which is then entered into tools that support the process of achieving the objectives of the company. The tools as marketing are using the power of social media such as Instagram and Facebook. Those two applications had been chosen because it is considered to have a good level of business prospects and has a rapidly increasing the user level. The accounts of each social media that have been made are as directed in Figure 2 and 3.

\section{RESEARCH METHODOLOGY}

The research method used in this research is qualitative method. The qualitative method itself is a study that discusses descriptive research and tends to use analysis. Process and meaning (subject perspective) are more highlighted in qualitative research. The theoretical foundation is used as a guide so that the focus of the research is in accordance with the facts in the field. In addition, the theoretical basis is also useful to provide an overview of the research setting and as a material for discussion of research results [13].

While the data collection techniques performed by interview method. The steps taken in this study included problem identification, literature study, data collection, problem analysis related to the application of the concept of Customer Relationship Management (CRM) and the drawing of research conclusions. At the identification phase of the problem carried out by the first author is to conduct a direct interview on 8 April 2018 with C.A.S. Tampawenas as the owner of Alexander Stamps Gallery with one of his management staff of the company in order to gather preliminary information regarding the business processes that exist at Alexander Stamps Gallery. Next, on the phase of literature study the author began by collecting data to meet the basic theory results obtained from the study of literature, as well as studying other reference sources derived from earlier research journals related. Then after the theoretical foundation obtained is considered sufficient as a rationale, the next process that is carried out is the author collected the data that has been obtained as material to continue to the next phase of the process. Later on the next phase is a phase of concept analysis of Customer Relationship Management (CRM) at the Alexander Stamps Gallery. The process carried out is adjusting the findings of the company's business processes, sales activities and the use of social media in the company for the purpose of retaining customers and increasing sales volume in the company. The expected results from this step is how the process of implementing the concept of Customer Relationship Management (CRM) in the company can run well and become a guide in how to maintain customer loyalty and increase sales volume at Alexander Stamps Gallery.

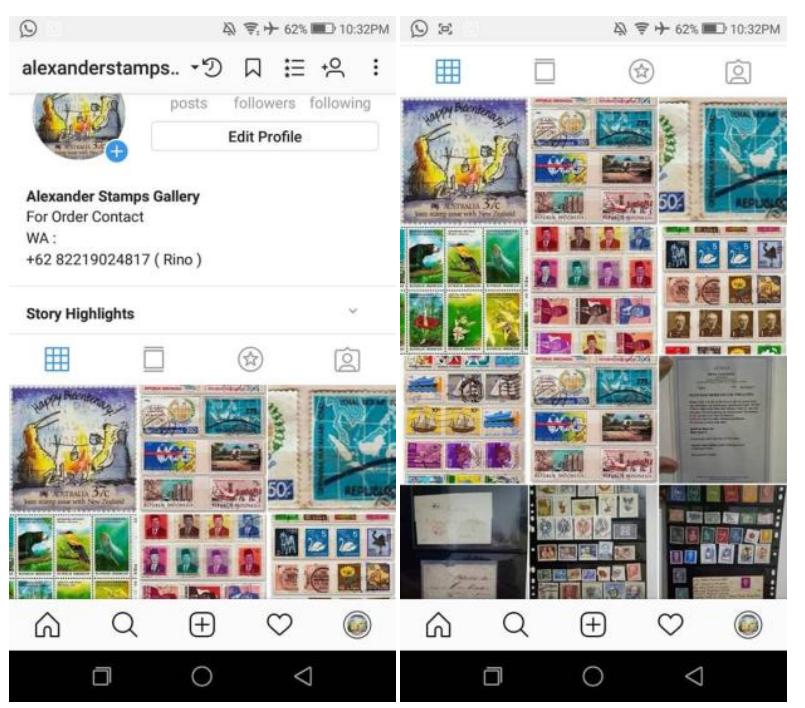

Figure 2. Account Instagram @ alexanderstampsgallery 


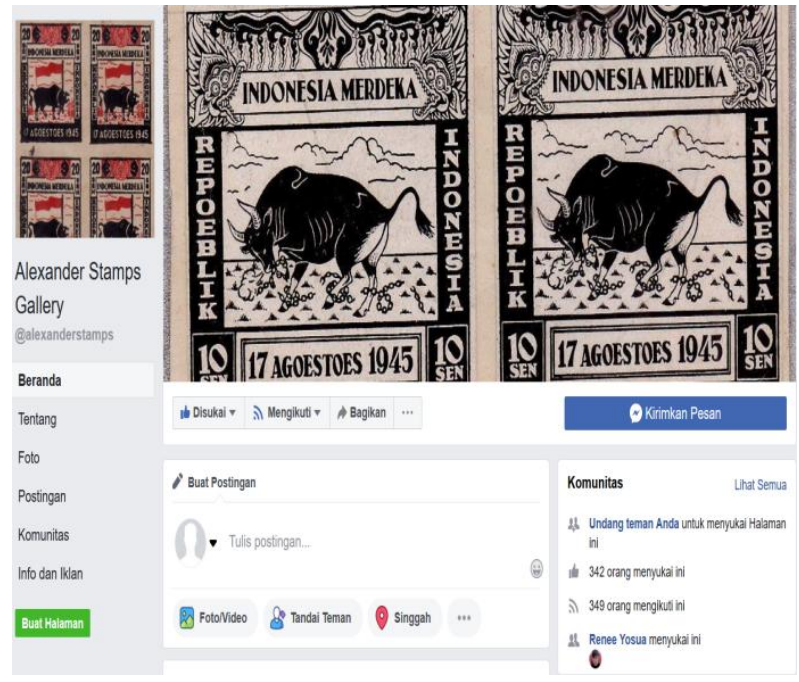

Figure 3. Facebook account named Alexander Stamps Gallery

Social media plays a role as a work supporter of each business process carried out by a company and its implementation in supporting E-CRM in running its role, social media functions as web 2.0 which means that there is an interaction process between social media manager at Alexander Stamps Gallery and its customers who buys goods. This is exactly become a strength of a company companies that are heading to the use of the E-CRM concept as a medium for marketing goods, so the focus of the E-CRM concept is on how to utilize marketing communication as as part of the social media utilization. Exploiting social media like Instagram and Facebook at Alexander Stamps Gallery would make E-CRM as the right breakthrough in achieving the goals of marketing companies to attract and retain loyal customers and efforts to increase the volume of sales of goods.

So that the results of the discussion above, the results are as follows:

\section{Encourage customer loyalty}

With the exploiting of Instagram and Facebook as a marketing medium create a closer relationship between the company and customers to interact, so it appears a trust between seller and buyer. Social media tools can also be used as a medium for marketing and promotion of goods. Customers who are said to have loyalty to the company tend to voluntarily help the company to promote products sold by the company so that it can be widely known

\section{Detract costs}

Information technology facilities in this case, social media in capturing and retaining customers no longer have to require large funds, because social media users can be quickly connected with the seller / company through content that is updated and published quickly and accurately. So that the effectiveness and efficiency in the delivery and receipt of messages makes the flow of information from the company to the customer can be conveyed better.

\section{Improve operational efficiency}

Social media can break down the risk of decreasing the quality of service and also can directly break down the cash flow burden on the company. The use of practical and easy social media facilities will directly reduce the obstacles that occur in the bureaucracy and the costs and administrative processes that may arise.

\section{Improved time to market}

By using social media facilities that can be accessed anytime and anywhere by all parties, so challenges such as time, geographical barriers, to the availability of data sources can be set aside to accelerate the sale of these products, so that time used is more efficient.

\section{Increased sales volume}

Social media tools are free to bring a positive impact both in terms of marketing, promotions up to speed in updating a product availability, so customers will be easier to find the necessary requirements as quickly and efficiently as possible. Great marketing on social media can also bring tremendous success to your business, create loyal supporters and even drive sales prospects and volumes to the target your company wants.

The result of the CRM implementation through Indtagram and Facebook as a marketing media for Alexander Stamps Gallery brings a good effect to the company. It is proven that an active social media of a company can show that the company is reliable and more hit the feeling and loyalty of the customers to trust the company. The Income at Alexander Gallery Stamps addressed in Figure 4.

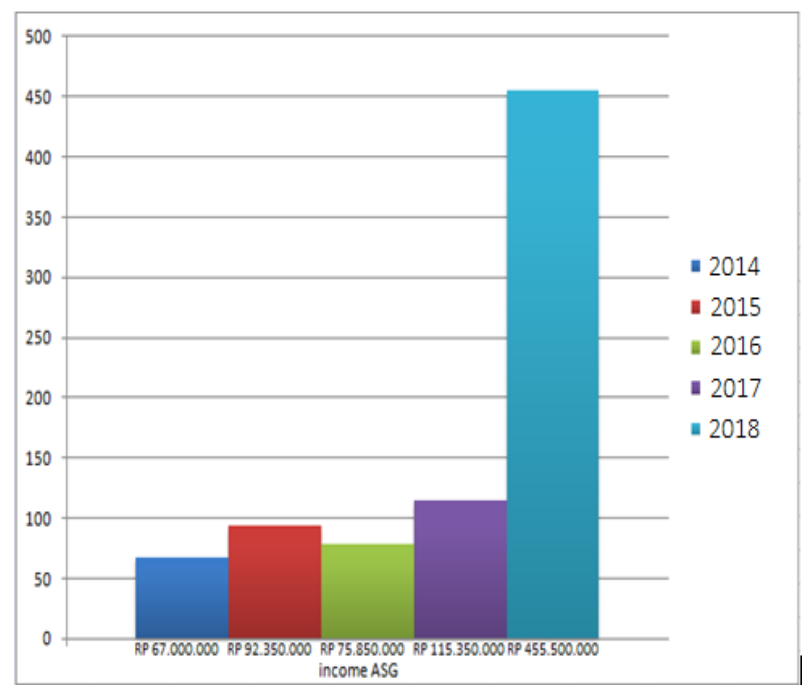

Figure 4. Income on Alexander Stamps Gallery.

The graph in Figure 4 above shows the sales volume at Alexander Stamps Gallery from 2014-2018. The highest increase occurred in 2017 to 2018 in which the implementation of CRM strategy plays an important role in company business processes resulting in a significant increase in corporate income. CRM strategies carried out in the Alexander Stamps Gallery business process include the promotion of social media such as Instagram and Facebook, which can drive the company's sales level. In another strategy, the company held an exhibition championship to get attention for new or old customers. Meanwhile, the impact felt by the company from organizing the event was considered positive because it directly affected the company's income which rose significantly.

Figure 5 shows that CRM implementation strategy plays an important role in boosting the level of income and sales volume at the Alexander Stamps Gallery. The CRM strategies 
applied to ASG through social media intermediaries include the Exhibition event that gets the top position with $50 \%$ of sales then online sales that get $25 \%$ as well as an auction and exhibition that gets 15 and $10 \%$ of sales. From the results, it can be concluded that social media is the best way to promote the products, so that it can be increased sales volume and customer loyalty at Alexander Stamps Gallery.

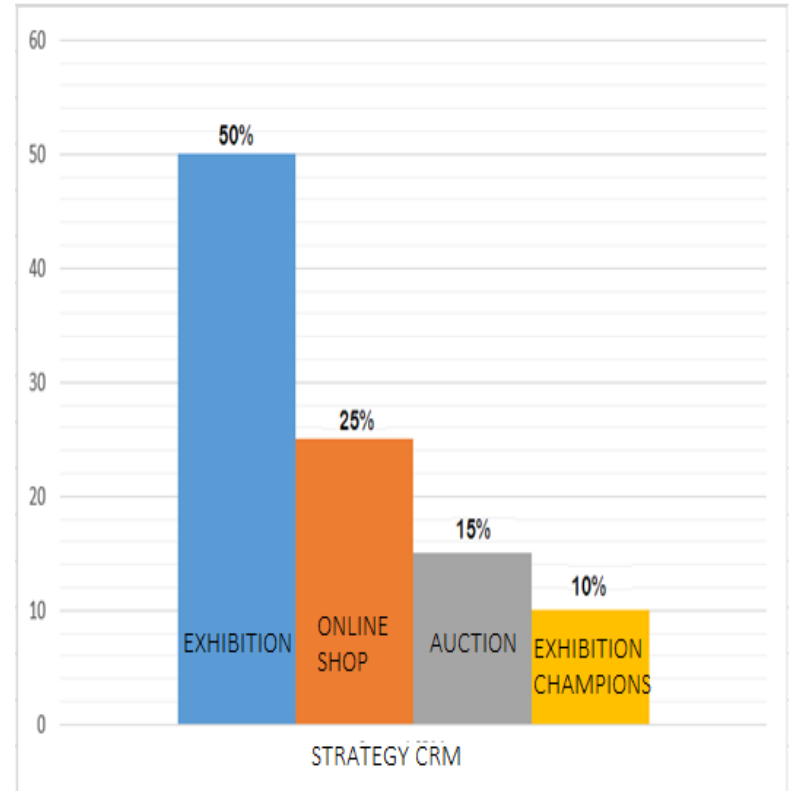

Figure 5. CRM Implementation Strategies at Alexander Stamps Gallery

\section{CONCLUSION AND SUGGESTIONS}

The conclusion than can be drawn from the above discussion is that social media is very helpful for Alexander Stamps Gallery with the aim to capture new customers, retaining customers and increasing sales volume amid intense business competition. The use of social media such as Instagram and Facebook shows that relatively more practical and manageable in achieving the company's marketing objectives. The concept of Customer Relationship Management (CRM) comes with placing both social media well in the midst of the company's business process. The result of the use of social media within the Customer Relationship Management concept brings good impact to the company indicated by an enhancement of sales volume coupled with an increasingly loyal customer.
The suggestion for this research is need a control system that functions as a consideration system in the company in making decision related to the CRM concept that has been implemented in the company that are constantly evolving to help companies maintain customer loyalty and increase sales volume at Alexander Stamps Gallery.

\section{REFERENCES}

[1] Michael J.Baker.2016. What is Marketing. Jakarta: Gramedia.

[2] esj.com/articles/2000/12/01/ebusiness-crm

[3] Yanuar Insanaputra (2017). "Pola Adopsi CRM oleh Pelaku Online Shop Berbasis Media Sosial. Seminar nasional teknologi informasi,komunikasi dan industry (SNTIKI) Pekanbaru, 18-19 Mei 2017.

[4] Theresia Pradiani (2017). "Pengaruh Sistem Pemasaran Digital Marketing Terhadap Peningkatan Volume Penjualan Hasil Industri Rumahan”. Jurnal JIBEKA Volume 11 Nomor 2 Februari 2017: 46-53.

[5] Radius Tanone dan Richard G Mayopu (2018). "Analisa Social Media dan Public Relation dalam Mendukung ECRM Studi Kasus: PT. Gunung Slamat Slawi”. Jurnal Sistem Informasi Indonesia (JSII) Volume 3 Nomor 1 (2018).

[6] V kumar, Werner Reinartz.2016.Customer Relationship Management: Concept, Strategy, and Tools.

[7] Francis Buttle and Stan Maklan.2003. Customer Relationship Management Concepts and Technologies.

[8] www.crmswitch.com/crm-training/using-andunderstanding-crm

[9] Jill Griffin.2002. Customer Loyalty: How to Earn It, How to Keep It. Jakarta: Gramedia.

[10] Jill Griffin.1995. Customer Loyalty: How to Earn It, How to Keep It.

[11] Francis Buttle.2004. Customer Relationship Management Concepts and Tools. Jakarta: Gramedia.

[12] Bruno Godey (2016). "Social media marketing efforts of luxury brands: Influence on brand equity and consumer behavior". Jurnal of bussines research volume 69, Issue 12, December 2016.

[13] wikipedia.org/wiki/Penelitian_kualitatif. 